\section{Ankara University Faculty of Educational Sciences Journal of Special Education}

2022, 23(3), 655-673
REVIEW

Recieved Date: 03.07.20

Accepted Date: 21.07.21

OnlineFirst: 25.09 .21

\title{
Language and Communication Features of Childhood-Onset Schizophrenia and Autism Spectrum Disorders: A Literature Review
}

\author{
Tuğçe Çabuk (iD) 1
}

\author{
Şevket Özdemir ${ }^{\left(D_{2} 2\right.}$
}

\begin{abstract}
Introduction: Schizophrenia (SZ) and autism spectrum disorders (ASD) both have life-long and negative impacts on the individuals. In contrast to ASD, SZ occurs "rarely" in childhood (before the age of 13) which is called childhood-onset schizophrenia (COS). Although COS and ASD have distinct pathologies, they exhibit common characteristics since they were described first. One of the most important commonalities is overlapping language and communication features. Till now, it is known that there is no integrative model related to the mutual language characteristics and underlying neurogenetic factors covering both of these disorders. Therefore, this literature review aimed to reveal previous research reporting both diverging and converging language issues with regards to these populations. The information presented in this review also aimed to help special education professionals about noticing the children who might present the features of COS. For this aim, firstly, the historical backgrounds of the disorders were given. Later, the language and communication features of COS and ASD including the overlapping characteristics were presented in light of previous research.

Discussion: Studies showed that pragmatic limitations could be observed within both populations. Atypical language characteristics such as echolalia and self-talk could also be mutually observed. A need for future studies exploring the morphological and semantic levels of COS and ASD was emphasized. Furthermore, it was proposed that retrospective and prospective studies could be designed with a large sample. The connection between language and pretend play or executive functions could be examined.
\end{abstract}

Keywords: Childhood-onset schizophrenia, autism spectrum disorders, language, communication, schizophrenia.

To cite: Çabuk, T., Özdemir, Ş., \& Töret, G. (2022). Language and communication features of childhood-onset schizophrenia and autism spectrum disorders: A literature review. Ankara University Faculty of Educational Sciences Journal of Special Education, 23(3), 655-673. https://doi.org/10.21565/ozelegitimdergisi.857651

\footnotetext{
${ }^{1}$ Speech and Language Therapist, PhD Candidate, İhsan Doğramac1 Bilkent University, E-mail: tugce.cabuk @ bilkent.edu.tr, https://orcid.org/0000-0003-1881-1349

${ }^{2}$ Corresponding Author: Assist. Prof., Muğla Sitk1 Koçman University, E-mail: sevketozdemir@mu.edu.tr, https://orcid.org/0000-0002-1230-6491

${ }^{3}$ Assist. Prof., Hacettepe University, E-mail: gokhan.toret@hacettepe.edu.tr, https://orcid.org/0000-0001-8801-2310
} 


\section{Introduction}

Schizophrenia (SZ) and autism spectrum disorders (ASD) both have life-long and negative impacts on the individuals. In Diagnostic and Statistical Manual of Mental Disorders (DSM-V; American Psychiatric Association [APA], 2013), the criteria for diagnosing a person with SZ which is a neuropsychiatric disorder has multiple dimensions. It starts "mostly" in late adolescence and early adulthood, presenting itself with the persistent symptoms such as hallucination, delusion, disordered thought and language which cause social and occupational disruptions (APA, 2013). It occurs "rarely" in childhood (generally before the age of 13). Therefore, it is called Childhood-Onset Schizophrenia (COS) (Remschmidt et al., 2006). On the other hand, ASD, a neurodevelopmental disorder, is defined with the symptoms including poor eye contact, problems in turn-taking, abnormal-persistent social communication, and limited-repetitive activities, behaviors, and interests (APA, 2013). Although COS and ASD have distinct pathologies, they have major behavioral and cognitive commonalities since they were described firstly. For instance, Kanner published seminal case series called "Autistic disturbances of affective contact" (Kanner, 1943). In these series, 11 young patients were described as suffering from infantile psychosis (as cited in Hommer \& Swedo, 2015). These commonalities include shared genetic and environmental factors, social cognition, thought, language and communication deficits, brain abnormalities which consist of neurobiological and neurophysiological features and clinical manifestations of the disorders (Barlati et al., 2016). In this review, we aim to provide suggestions regarding (i) language and communication features of both COS and ASD, (ii) common language and communication characteristics of COS and ASD, and (iii) future directions and its implication for the intervention.

SZ and ASD have a long history which is full of diagnostic confusion (Konstantareas \& Hewitt, 2001; Rapoport et al., 2009). When Emil Kraepelin first introduced "dementia praecox" -also known as SZ- in the late 1800 s, he managed to differentiate neurodegenerative diseases linked with cognitive impairments from "episodic affective disorders" (e.g. manic depression) (Ebert \& Bar, 2010). Later, Sante de Sanctis extended the description of the "dementia praecox" to the field of childhood psychiatry and named it as "dementia praecocissima" in which childhood symptoms such as psychotic situations and autism were observed together. These symptoms may refer in current literature to strangeness of character, apathy, depressed mood, hallucination and catatonia (Morgese \& Lombardo, 2019). As to autism, it was initially presented by Bleuler (Bleuler, 1950). He proposed it as a disorder exhibiting the symptoms of SZ rather than recognizing it as separate and distinct. Prior to the release of DSM-III which categorized ASD as a distinct pathology, ASD was diagnosed as COS, a childhood disorder consisting of abnormal reality perception and social functioning (APA, 1952, 1968; Grinker, 2008). Besides, a rare and severe form of ASD known as Heller's syndrome or childhood disintegrative disorder characterized by developmental regression was often associated with paranoia and psychosis (Trevisan et al., 2020). Likewise, the instances of hallucination and delusion were reported in Asperger syndrome (Arora et al., 2011; Jansch \& Hare, 2014). Although these syndromes are now under ASD in DSM-V (APA, 2013), these proposals could demonstrate that the symptoms of ASD and SZ could overlap (Trevisan et al., 2020).

Current studies still report overlapping but inconsistent findings (Meyer et al., 2011). At the behavioral level, deficits in social cognition, executive functioning, disruption in emotional processing and delayed language were observed among these disorders (Cheung et al., 2010; Gernsbacher et al., 2016; Nicholson et al., 2000; Rapin $\&$ Tuchman, 2008). Furthermore, previous studies on brain morphological level reported structural and functional abnormalities in cerebellum, insular cortex, fusiform gyrus in both of these disorders (Cheung et al., 2010; McAlonan et al., 2005; Shenton et al., 2001; Toal et al., 2009). As shown by fMRI ${ }^{1}$, individuals with SZ and ASD showed reduced activation in fusiform gyrus, right amygdala and ventrolateral prefrontal cortex as they performed poorly in social cognition tasks (Pinkham et al., 2008). Moreover, a meta-analysis study showed brain structural concordance between these disorders (Cheung et al., 2010). The structural areas specific to this concordance involved right parahippocampal gyrus, putamen, posterior cingulate, claustrum and left thalamus (Cheung et al., 2010). Besides, $\mathrm{DTI}^{2}$ studies demonstrated the decreased white matter integrity in superior longitudinal fasciculus (a very important region about language processing) (Baribeau \& Anagnostou, 2013). At the cellular level, one of the most known biomarker altered in both disorders is Reelin (Fatemi, 2005). It is effective in early neurodevelopmental stages. It provides "a detachment signal for migrating cell". It is known that reduced Reelin

${ }^{1} \mathrm{fMRI}$ is a neuroimaging technique which "takes advantage of the coupling between neuronal activity and haemodynamics (the local control of blood flow and oxygenation) in the brain to allow non-invasive localization and measurement of brain activity" (Heeger \& Ress, 2002).

${ }^{2}$ DTI is a neuroimaging technique which shows the diffusion profile of water molecules at three dimensional voxels (Le Bihan et al., 1986). It gives information about demyelination and axonal damage. 
signaling may contribute to a delay in neurodevelopmental stages among SZ and ASD (Fatemi, 2005). In neurochemical level, there could also be deficits pertaining to serotonergic system in these disorders. For instance, like SZ patients, individuals with ASD may experience abnormality in serotonin synthesis capacity and serotonin receptor dysfunctions (Abi-Dargham et al., 1997; Lam et al., 2006). Lastly, environmental and genetic factors could be shared in SZ and ASD such as prenatal exposure to infection, parental age, prenatal stress and the genes including CNTNAP2 (seen as a marker in language disturbances) and NRXN1 (Barlati, 2016; Meyer et al., 2011). To sum up, behavioral studies showed similarities in terms of language domain since the discovery of SZ and ASD. Some examples of previous research on brain and genetics support this viewpoint. However, other previous studies report diverging language characteristics despite mutual language problems. There is no integrative model related to the mutual language characteristics and underlying neural and genetic factors covering both of these disorders. Therefore, this literature review aims (i) to reveal and discuss previous research reporting both diverging and converging language issues with regards to these populations and (ii) help special education professionals about noticing the children who might present the feature of COS. As a result, the professionals might refer these children for psychiatric assessment through which they can contribute to differential diagnosis along with the provision of appropriate intervention.

\section{Key Language and Communication Features in Childhood-Onset Schizophrenia}

COS is seen as a rare and more severe type of SZ (Hart \& Lewine, 2017). Formal/Thought Disorder (FTD/TD) or "language and communication disorders in SZ" is one of the core clinical symptoms in COS (Hart \& Lewine, 2017). It can be defined as "any disturbances that affect the form of thinking, including the organization, control, processing, or expression of thoughts" (Hart \& Lewine, 2017). The clinical signs consist of illogical thinking, incoherence, loose associations in the conversation (derailment) and poverty of speech content (APA, 2013). These signs also define FTD which is the result of impaired cognitive and linguistic (including pragmatic) skills (Caplan, 1994). Additional signs include derailment, tangentiality (i.e. tendency to speak about other topics which are not related to the main topic of the discourse), circumstantiality (i.e. fulfilling the conversation with unnecessary and irrelevant details and experiencing challenges to reach the main point), echolalia and perseveration (Andreasen, 1979).

Few studies (Arbodela \& Holzman, 1985; Cantor et al., 1982; Caplan, 1994; Kolvin, 1971) examined language and communication features specific to COS. These studies proved that children with SZ exhibited symptoms such as derailment (Arbodela \& Holzman, 1985), neologism (i.e. creating a new word such as "mersku") (Cantor et al., 1982), clanging (i.e. forming the structure of conversation based on the sound of words rather than the concept) (Arbodela \& Holzman, 1985; Cantor et al., 1982), illogicality (Cantor et al., 1982; Caplan, 1994), poverty of speech content (Caplan, 1994). Especially deficits related to pragmatics and discourse were observed in COS (Caplan, 1994). More specifically, children with SZ produced a smaller number of utterances compared to the typical condition. They did not utilize enough number of cohesive links between the utterances. They did not use enough number of references to people, objects and events mentioned earlier among these utterances (Caplan, 1994; Caplan et al., 1992). This resulted in loose associations and confused the listeners as the references were ambiguous (Harvey \& Brault, 1986). Furthermore, they produced a smaller number of conjunctions between contiguous clauses (i.e. Tuğçe went to the grocery. She bought garlic), repeated words or word roots known as lexical cohesion less than typically-developing children. They also omitted parts of previous clause as they thought the listener already received and possessed the information (otherwise called as "ellipsis"). They significantly utilized more exophora and fewer words per clause which yielded simple sentences in terms of syntactic complexity. These patterns led to pragmatic and discourse deficits that challenged the listeners to understand the speech of children with SZ and make connections between the sentences (Caplan, 1994). Baltaxe and Simmons (1988) used a taxonomy about the aforementioned deficits in COS. These involved the following: (1) referencing (deficit in providing enough background information to the listeners for the formation of discourse, switching between or within the references in an inappropriate way, using non-contextual situational reference, failure to understand the connection between old and new information, and using ellipsis); (2) switching (failing to create a topic, expanding the topic into a contextually-inappropriate one, and switching the topic to the self); (3) sequencing of discourse (experiencing the challenge to retrieve and order appropriate and logical utterances while describing an event) and (4) turn-taking problems. Children with schizophrenia also had difficulty to understand abstract concepts in the language (Baltaxe \& Simmons, 1995). Besides, speech dysfluencies including the pauses and false starts were observed among these children. It was suggested that these dysfluencies might have implied pragmatic deficits (Baltaxe \& Simmons, 1995). 
The vocabulary and syntax were also impaired (Baltaxe \& Simmons, 1995) in that the children with schizophrenia had lower receptive and expressive vocabulary scores compared to the controls (Waterhouse \& Fein, 1984; Fish, 1987). Moreover, these children had problems related to comprehending syntactically complex sentences, and produced a smaller number of such sentences (Baltaxe \& Simons, 1995). As observed in schizophrenia during adulthood, children with SZ had expressive prosody deficits such as affective flattening while speaking (Baltaxe \& Simons, 1995).

\section{Key Language and Communication Features in Autism Spectrum Disorders}

ASD is a neurodevelopmental disorder. The diagnosis is confirmed through a combination of three essential symptoms prior to the age of three: (a) Deficits in social interaction and (b) language, (c) stereotypical behaviors that lead to significant problems during daily life routines (APA, 2013). In this respect, ASD involves considerable challenges regarding social interaction, symbolic play, verbal and non-verbal communication. It is classified according to the severity of how these areas are affected (APA, 2013). Some argue that language problems need to be included into the diagnostic process as children with ASD experience significant challenges both in receptive and expressive language. Approximately half of the children with ASD is reported to be nonverbal as these children might not have any functional verbal output (Prelock et al., 2011). Those who are verbal might have issues regarding how to make sentences according to the rules of the language in terms of syntactic development (Roth \& Worthington, 2015). The language development milestones as observed and measured among typically-developing children might not be applicable to ASD whose language development is aberrant. Moreover, retrospective studies showed that language regression could be observed among these children between 12 and 24 months of age (Landa \& Garrett-Mayer, 2006; Ozonoff et al., 2010). The language development profiles of children with ASD are heterogeneous (Paul \& Norbury, 2011; Roth \&Worthington, 2015).

Regarding the prelinguistic communication, there are six important issues observed among children with ASD: Atypical vocalization (Patten et al., 2014), a delay in pointing to refer to an object or person (Dawson et al., 1998; Stone et al., 1997), giving no reaction or feedback when the name of the child is uttered (Osterling \& Dawson, 1994; Paul et al., 2007), limitations in imitating the actions or vocalizations of other people (Volkmar et al., 1997), inability to form shared attention (Paul \& Norbury, 2011; Töret \& Acarlar, 2011). These issues challenge the children with ASD to pass onto the subsequent stages from pre-linguistic communication. These problems cause limitations in all the components of language including vocabulary, morphosyntactic structures and use of these structures in appropriate contexts (Roth \& Worthington, 2015). These important issues are also designated as "red flags" that could distinguish the developmental profile of children with ASD from typicallydeveloping children or those having language delays without any concomitant challenge or disorders (Gabrielsen et al., 2015; Landa \& Garrett-Mayer, 2006; Wetherby et al., 2004).

Those with ASD who pass their two years continue to have significant problems. First, they have limited vocabulary and may not transition to two- or three-word combinations. Such difficulties are attested to the fact that they may not acquire or grasp the connection between the words that are semantically related (Eigsti et al., 2011; Kamio et al., 2007). Second, they still have persistent problems in imitation, eye contact, joint attention and the use of gesture and mimics. Especially, these problems are manifested in the unwillingness or indifference to engaging communication with other people or responding to their communication attempts (Roth \& Worthington, 2015; Tager-Flusberg \& Anderson, 1991). Third, they may not understand, process and produce expressions bearing emotional valence as a result of issues with empathy. This triggers further problems that may hinder any contextually-appropriate responses to these expressions. However, it is observed that they refer to themselves as a third person as an atypical feature of using personal pronouns (Eigsti \& Bennetto, 2009). Lastly, they have persistent echolalia which holds negative impact on the language development of children with ASD (Paul \& Norbury, 2011; Prelock et al., 2011; Roth \& Worthington, 2015). The language and communication characteristics of children with COS and ASD were mentioned in separate sections. Therefore, in the following section, the question of whether the language and communication abnormalities in COS and ASD overlap was addressed.

\section{Discussion}

\section{Do the Language and Communication Abnormalities in Childhood-Onset Schizophrenia and Autism Spectrum Disorders Overlap?}

The language and communication disturbances within COS and ASD are common in that they might be the pieces of the same puzzle. Focusing on speech disorganization, we observe that it is the result of disorganized thoughts. The individuals with ASD produce unrelated utterances in a disorganized manner or with little variety, 
and these utterances do not fit the actual conversation flow (Stefanatos \& Baron, 2011). Interestingly, we address similar speech patterns among COS. Children with SZ experience issues such as loose association in a topic, switching the topics fast from one to another, using confused and repetitive speech, producing inappropriate words without meanings (Alary et al., 2013).

Lewis et al. (2009) point out that the poverty of speech referring to the decrease in verbal communication and consisting of empty and brief responses to questions is seen among both ASD/Asperger Syndrome and COS/SZ. Repetitive conversation is prevalent and common among these disorders (Fitzgerald, 2012). The speech of ASD/Asperger Syndrome and COS/SZ consists of the features such as tangentiality. Both populations experience "slip of the track" and "the associative chain moves obliquely off topic" (Lewis, 2009). We can often come across neologism and echolalia (Fitzgerald, 2012). Besides, these individuals provide unnecessary details during the conversations (Fitzgerald, 2012; Thaker, 2009). Individuals with severe ASD can be non-verbal and have aprosody (i.e., using a monotone voice) (Persico \& Napolioni, 2013). This aprosody refers to flattened intonation in COS. Lastly, self-talk and circumstantiality in speech are frequently observed in both conditions (Fitzgerald, 2010).

Difficulties in social communication and social-emotional exchange are the main overlapping diagnostic features that might result in confusion in clinical practice. These difficulties include lack of willingness to share emotions, lack of eye contact, lack of or limited use of facial expressions-gestures and restricted initiation of spontaneous communication (Barlati et al., 2016; Fitzgerald, 2012; Trevisan et al., 2020). These were reported to have mutual neural origins as reduced activation in ventrolateral prefrontal cortex, right amygdala, fusiform face area were observed, which might have resulted in social communication problems among these populations (Pinkham et al., 2008; Couture et al., 2010). However, such common characteristics might slightly differ, as reported by a recent study by Trevisan et al. (2020). They included 39 SZ and 53 ASD participants who ages ranged from 18 to 48. They utilized Autism Diagnostic Observation Schedule-2 (ADOS-2) to discriminate ASD from SZ and explore any diverging characteristics between these disorders. The disorder-specific features included hallucinations, delusions and bizarre behaviors such as talking to oneself in SZ whereas these were lacking in ASD where echolalia and atypical social behaviors were observed (Trevisan et al., 2020). These features might converge as well, leading the clinicians into dual diagnosis which is reported to be more frequent than previously envisaged (Foss-Feig, 2019). There were subtleties in terms of rating 11 items in ADOS-2. As authors exemplified, one of them was related to eye contact which was absent among the individuals with ASD. However, the ones with SZ exhibited an atypical behavior pattern such as "staring unrelentingly" in terms of eye contact (Trevisan et al., 2020).

In sum, the language problems experienced by children with ASD and SZ could refer to a delay in the language development and its extraordinary nature. Taking into account this delay in terms of the components of language, pragmatic limitations could be observed within both populations (e.g., the use of gesture, words, etc. appropriate to communicative intentions). Atypical language characteristics including echolalia and self-talk could also be mutually observed. However, previous studies examining the language problems within the field of morphology and semantics are limited (Baltaxe \& Simmons, 1995; Fish, 1987; Waterhouse \& Fein, 1984). Even though the studies carried out in the last 30 years signify a delayed language including limited vocabulary production; it would be a speculative comment to suggest that there are mutual morphological and semantic problems due to the heterogeneous nature of language in ASD, sample variability, differences in data collection tools, etc. Therefore, future comparison studies targeting a wide range of language components should be conducted.

\section{Future Directions and Its Implications for the Intervention Strategies}

COS and ASD are among the disorders whose diagnosis and management are updated by the literature of clinical and applied sciences. Even though the language and social communication development are the common deficit areas within both disorders, professionals have more opportunities in the decision of evidence-based practice within ASD compared to COS. For instance, there is a scientific report documenting the options of evidence-based intervention in ASD according to certain criteria (National Autism Center [NAC], 2009, 2015). This is not available for COS through which professionals may benefit in intervention. This is also due to the fact that the diagnosis of COS might not be stable throughout the childhood (Trevisan et al., 2020). Having regular communication with the child psychiatrist is a fundamental part of extracting the best performance from the children with either single (COS) or dual (COS and ASD) diagnoses. There might be additional issues including hallucinations, decline in hygiene, affective and behavioral instability that need to be taken into account in the 
assessment of COS (Li et al., 2010). Albeit a wide variety of different comorbidities (including COS and ASD, Attention Deficit Hyperactivity Disorder, Learning Disabilities, Intellectual Disabilities), anxiety and depression levels are reported to be high in the children with COS, which in turn affects academic performance (Chen et al., 2017; Li et al., 2010; Myles-Worsley et al., 2017). Therefore, future studies might compare the language features (i.e., communication functions in the use of language), non-verbal social communication development relevant to language (i.e., imitation) and academic competence (i.e., reading comprehension) within both groups. These studies might also compare the effects of focused intervention methods including Enhanced Milieu Teaching used widely in ASD. On the other hand, these two disorders might show differences in terms of the intervention approaches. The primary intervention in ASD includes educational intervention approaches. These might be grouped into methods based on applied behavior analysis (Smith, 2001), those based on natural, behavioral, and developmental approaches (Hancock \& Kaiser, 2002), and alternative and augmentative communication (Schlosser \& Wendt, 2008). However, the primary intervention in COS, as in SZ, is the pharmacological treatment (Li et al., 2010; Vyas \& Gogtay, 2012). The secondary (but the most complementary) one includes the psychosocial intervention approaches: Family intervention and social skills training. However, these approaches were predominantly tested with adult patients with SZ. Due to these reasons, a comprehensive and integrative approach needs to be adopted where different options could be utilized together in the intervention process.

The parent-mediated intervention requires active participation of parental members. It needs to target how environmental distressors could be reduced to improve problem-solving skills and psycho-social functioning (Clark \& Lewis, 1998; Hernandez et al., 2013). It also aims to facilitate the adaptation process of family members in terms of the side-effects of the pharmacological treatment and available academic support programs tailored to individual needs of their children with COS (Hall \& Bean, 2008). It includes key strategies such as role playing, rehearsal and homework through which following contents are demonstrated to the family: They are expected to understand the nature of the COS, improve their coping mechanisms, develop their problem-solving skills and more importantly, foster their communication with their children with COS (Li et al., 2010) The primary goal of the family intervention is to significantly eliminate the risk/rates of relapse (and re-hospitalization, if applicable). It also helps parental members be less overprotective, resulting in a smaller number of social withdrawal instances. The overprotective nature of parents and the social withdrawal from peers were reported to contribute to low levels of social competence among children with COS (Kopelowicz et al., 2006).

The second intervention is social skills training. As previous literature is heavily based on the adults, the reviews on COS suggest a careful adaptation of social skill training strategies utilized among the adult population for the younger one (including children and adolescents with COS) (Dulmus \& Smyth, 2000; Stafford et al., 2015). The benefits of social skills training has been extensively reported; including eye contact, content of speech, engagement into conversation, higher levels of social adaptation (Dulmus \& Smyth, 2000; Wallace \& Liberman, 1985). This training also helps the individual adhere to the pharmacological treatment which is the primary source of intervention (Kopelowicz et al., 2006; Liebarman \& Kopelowicz, 2005). It involves procedures such as problem identification, goal setting, role playing, positive feedback, social modeling, behavioral practice, positive social reinforcement, homework assignments (Kopelowicz et al., 2006; Li et al., 2010; Rus-Calafell et al., 2014). During the training, the skills to be gained as part of the long-term goal is broken down into its small components, resulting in the task analysis. These components hold significant and practical contributions to effective use of verbal/nonverbal communication and conversation skills (initiating, maintaining, and terminating the conversation). In parallel with the ASD (Olçay-Gül \& Tekin-İftar, 2016), the ultimate aim is to help individuals with SZ learn, retain and transfer these skills (Kopelowicz et al., 2006; Li et al., 2010; Rus-Calafell et al., 2014).

One retrospective study (Li et al., 2010) indicates poor academic performances and high rates of school drop-outs. Problems related to academic performance are observed while staying in the seats for longer duration, storing and retrieving information, attuning to the teacher without experiencing any distractions, grasping the content of the curriculum, generating appropriate responses to the queries of the teachers, and participating in the examinations. These are especially relevant for courses where there is more amount of social interaction than others (such as math vs. language) (Li et al., 2010). The availability of mental health professionals and active participation of families were emphasized to grasp the multidimensional nature of this population in the special education process. Psychosocial interventions including social skills training were named as the key route for the educational intervention which was also seen as a possible solution to remediate peer interactions (Ball et al., 2018).

As stated previously, any suggestion includes the developmental adaptation or modification of the treatment options available for adult population ( $\mathrm{Li}$ et al., 2010). In addition, it is recommended that a considerably 

SPECTRUM DISORDERS: A LITERATURE REVIEW

larger evidence base of ASD interventions would be considered. More specifically, the language characteristics of ASD and COS could be examined in a large sample whose developmental levels are matched. Moreover, retrospective studies investigating the pre-linguistic communication features of children with ASD and COS prior to the diagnostic process could be conducted. Thus, a comprehensive language profile of these two groups will be identified. A better understanding of the language profiles of these two groups will strengthen the motivation of prospective experimental studies examining the effects of the language intervention approaches utilized in ASD on the language levels of COS. Moreover, parental views on the communication challenges observed in daily life among children with ASD and COS could be determined on a qualitative basis. The connection between language and pretend play or executive functions (attention, working memory, etc.) could be examined, which could make a significant contribution to exploring the mutual language problems following the results of these measuring procedures.

Even though recent literature stresses the comorbid emergence of ASD and COS, it is important for the professionals (including special education teachers, speech-language therapists, psychiatrists, and allied health and education professionals) to grasp the distinction between the issues related to social interaction as they can be subtle, resulting in over-diagnosis. The lack of estimate regarding the prevalence of this comorbidity makes it also difficult to make such a distinction. It is reported that distinguishing ASD from COS is a very complex diagnostic process where clinical experience, family history and longer periods of follow-up of the child might play significant roles in the diagnostic discrimination. It is suggested that following the child with a suspected (dual) diagnoses of ASD and COS longitudinally might be very beneficial in that SZ might be evident as the child ages (Galli-Carminati et al., 2017; Trevisan et al., 2020).

\section{Authors' Contributions}

The authors took equal roles in all parts of the research. 


\section{References}

Abi-Dargham, A., Laruelle, M., Aghajanian, G. K., Charney, D., \& Krystal, J. (1997). The role of serotonin in the pathophysiology and treatment of schizophrenia. Journal of Neuropsychiatry and Clinical Neurosciences, 9(1), 1-17. https://doi.org/10.1176/jnp.9.1.1

Alary, M., Delcroix, N., Leroux, E., Razafimandimby, A., Brazo, P., Delamillieure, P., \& Dollfus, S. (2013). Functional hemispheric lateralization for language in patients with schizophrenia. Schizophrenia Research, 149(1-3), 42-47. https://doi.org/10.1016/j.schres.2013.06.003

American Psychiatric Association. (1952). Diagnostic and statistical manual of mental disorders (DSM-I) (1st ed.). American Psychiatric Publishing.

American Psychiatric Association. (1968). Diagnostic and statistical manual of mental disorders (DSM-II) (2nd ed.). American Psychiatric Publishing.

American Psychiatric Association. (2013). Diagnostic and statistical manual of mental disorders (DSM-V). (5th ed.) American Psychiatric Publishing.

Andreasen, N. C. (1979). Thought, language, and communication disorders. Archives of General Psychiatry, 36(12), 1315-1321. https://doi.org/10.1001/archpsyc.1979.01780120045006

Arboleda, C., \& Holzman, P. S. (1985). Thought disorder in children at risk for psychosis. Archives of General Psychiatry, 42(14), 1004-1013. https://doi.org/10.1001/archpsyc.1985.01790330084010

Arora, M., Praharaj, S. K., Sarkhel, S., \& Sinha, V. K. (2011). Asperger disorder in adults. Southern Medical Journal, 104(4), 264-268. https://doi.org/10.1097/SMJ.0b013e31820c015d

Ball, A., Rittner, B., Chen, Y., \& Maguin, E. (2018). Impact of individualized education plans on academic success of youth with early onset schizophrenia. Journal of Evidence-Informed Social Work, 15(5), 534-549. https://doi.org/10.1080/23761407.2018.1487356

Baltaxe, C. A. M., \& Simmons, J. Q. (1988). Communication deficits in preschool children with psychiatric disorders. Seminars in Speech and Language, 9(1), 81-91. https://doi.org/10.21565/ozelegitimdergisi.857651

Baltaxe, C. A. M., \& Simmons, J. Q. (1995). Speech and language disorders in children and adolescents with schizophrenia. Schizoprenia Bulletin, 21(4), 677-692. https://doi.org/10.1093/schbul/21.4.677

Baribeau, D. A., \& Anagnostou, E. (2013). A comparison of neuroimaging findings in childhood onset schizophrenia and autism spectrum disorder: A review of the literature. Frontiers in Psychiatry, 20(4), 115. https://doi.org/10.3389/fpsyt.2013.00175

Barlati, S., Deste, G., Ariu, C., \& Vita, A. (2016). Autism spectrum disorder and schizophrenia: Do they overlap? International Journal of Emergency Mental Health and Human Resilience, 18(1), 760-763. https://www.researchgate.net/publication/301287742_Autism_Spectrum_Disorder_and_Schizophrenia Do_They_Overlap

Bleuler, E. (1950). Dementia praecox or the group of schizophrenias. International Universities Press.

Cantor, S., Evans, J., Pearce, J., \& Pezzot-Pearce, T. (1982). Childhood schizophrenia: Present but not accounted for. American Journal of Psychiatry, 139(6), 758-763. https://doi.org/10.1176/ajp.139.6.758

Caplan, R. (1994). Communication deficits in childhood schizophrenia spectrum disorders. Schizophrenia Bulletin, 20(4), 671-683. https://doi.org/10.1093/schbul/20.4.671

Caplan, R., Guthrie, D., \& Foy, J. G. (1992). Communication deficits and formal thought disorder in schizophrenic children. Journal of the American Academy of Child and Adolescent Psychiatry, 31(1), 151-159. https://doi.org/10.1097/00004583-199201000-00023

Chen, Y., Rittner, B., Maguin, E., \& Dziadaszek, S. (2017). "I need a cigarette"-The effects of cigarette smoking on depression and anxiety of youth with early onset schizophrenia. Journal of Psychologists and Counsellors in Schools, 27(1), 70-84. https://doi.org/10.1017/jgc.2016.16 
Cheung, C., Yu, K., Fung, G., Leung, M., Wong, C., Li, Q., Sham, P., Chua, S., \& McAlonan, G. (2010). Autistic disorders and schizophrenia: Related or remote? An anatomical likelihood estimation. PLoS One, 5(8), e12233. https://doi.org/10.1371/journal.pone.0012233

Clark, A. F., \& Lewis, S. W. (1998). Practitioner review: Treatment of schizophrenia in childhood and adolescence. Journal of Child Psychology and Psychiatry, 39(8), 1071-1081. https://doi.org/10.1111/1469-7610.00412

Couture, S. M., Penn, D. L., Losh, M., Adolphs, R., Hurley, R., \& Piven, J. (2010). Comparison of social cognitive functioning in schizophrenia and high functioning autism: More convergence than divergence. Psychological Medicine, 40(4), 569-579. https://doi.org/10.1017/S003329170999078X

Dawson, G., Meltzoff, A., Osterling, J., \& Rinaldi, J. (1998). Neuropsychological correlates of early symptoms of autism. Child Development, 69(5), 1276-1285. https://doi.org/10.2307/1132265

Dulmus, C. N., \& Smyth, N. J. (2000). Early-onset schizophrenia: A literature review of empirically based interventions. Child and Adolescent Social Work Journal, 17(1), 55-69. https://doi.org/10.1023/A:1007567609909

Ebert, A., \& Bar, K. (2010). Emil Kraepelin: A pioneer of scientific understanding of psychiatry and psychopharmacology. Indian Journal of Psychiatry, 52(2), 191-192. https://doi.org/10.4103/0019-5545.64591

Eigsti, I. M., \& Bennetto, L. (2009). Grammaticality judgements in autism: Deviance or delay. Journal of Child Language, 36(5), 999-1021. https://doi.org/10.1017/S0305000909009362

Eigsti, I. M., de Marchena, A. B., Schuh, J. M., \& Kelley, E. (2011). Language acquisition in autism spectrum disorders: A developmental review. Research in Autism Spectrum Disorders, 52(2), 681-691. https://doi.org/10.1016/j.rasd.2010.09.001

Fatemi, S. H. (2005). Reelin glycoprotein: Structure, biology and roles in health and disease. Molecular Psychiatry, 10(3), 251-257. https://doi.org/10.1038/sj.mp.4001613

Fish, B. (1987). Infant predictors of the longitudinal course of schizophrenic development. Schizophrenia Bulletin, 13(3), 395-409. https://doi.org/10.1093/schbul/13.3.395

Fitzgerald, M. (2010). Young, violent and dangerous to know. Nova Science Publishers.

Fitzgerald, M. (2012). Schizophrenia and autism/Asperger's syndrome: Overlap and difference. Clinical Neuropsychiatry, 9(4), 171-176.

Foss-Feig, J. H. (2019). Looking under the hood of convergent behavioral deficits in schizophrenia and autism. Biological Psychiatry, 86(7), e21-e23. https://doi.org/10.1016/j.biopsych.2019.07.030

Gabrielsen, T. P., Farley, M., Speer, L., Villalobos, M., Baker, C. N., \& Miller, J. (2015). Identifying autism in a brief observation. Pediatrics, 135(2), 330-338. https://doi.org/10.1542/peds.2014-1428

Galli-Carminati, G., Tagan, C., Zecca, G., \& Carminati, F. (2018). Between autistic spectrum disorder (ASD) and childhood onset schizophrenia (COS): A proposal for a passerella syndrome. Neuropsychiatry (London), 8(4), 1239-1248. https://doi.org/10.4172/Neuropsychiatry.1000453

Gernsbacher, M. A., Morson, E. M., \& Grace, E. J. (2016). Language and speech in autism. Annual Review of Linguistics, 2(1), 413-425. https://doi.org/10.1146/annurev-linguist-030514-124824

Grinker, R. R. (2008). Unstrange minds: Remapping the world of autism. Basic Books.

Hall, S. D., \& Bean, R. A. (2008). Family therapy and childhood-onset schizophrenia: Pursuing clinical and bio/psycho/social competence. Contemporary Family Therapy, 30(2), 61-74. https://doi.org/10.1007/s10591-008-9061-7

Hancock, T. B., \& Kaiser, A. P. (2002). The effects of trainer-implemented Enhanced Milieu Teaching on the social communication of children with autism. Topics in Early Childhood Special Education, 22(1), 3954. https://doi.org/10.1177/027112140202200104 
Hart, M., \& Lewine, R. R. J. (2017). Rethinking thought disorder. Schizophrenia Bulletin, 43(3), 514-522. https://doi.org/10.1093/schbul/sbx003

Harvey, P. D., \& Brault, J. (1986). Speech performance in mania and schizophrenia: The association of positive and negative thought disorders and reference failures. Journal of Communication Disorders, 19(3), 161173. https://doi.org/10.1016/0021-9924(86)90006-7

Heeger, D. J., \& Ress, D. (2002). What does fMRI tell us about neuronal activity? Nature Reviews Neuroscience, 3, 142-151. https://doi.org/10.1038/nrn730

Hernandez, R. J. C., Rime, W. J., \& Jimerson, S. R. (2013). The school psychologist's primer on early onset schizophrenia: A review of research regarding epidemiology, etiology, assessment, and treatment. Contemporary School Psychology, 17(1), 51-69. https://psycnet.apa.org/record/2014-00087-005

Hommer, R. E., \& Swedo, S. E. (2015). Schizophrenia and autism-related disorders. Schizophrenia Bulletin, 41(2), 313-314. https://doi.org/10.1093/schbul/sbu188

Jänsch, C., \& Hare, D. J. (2014). An investigation of the "jumping to conclusions" data gathering bias and paranoid thoughts in asperger syndrome. Journal of Autism and Developmental Disorders, 44(1), 111-119. https://doi.org/10.1007/s10803-013-1855-2

Kamio, Y., Robins, D., Kelley, E., Swainson, B., \& Fein, D. (2007). Atypical lexical/semantic processing in highfunctioning autism spectrum disorders without early language delay. Journal of Autism and Developmental Disorders, 37(6) 1116-1122. https://doi.org/10.1007/s10803-006-0254-3

Kanner, L. (1943). Autistic disturbances of affective contact. Nervous Child, 2, 217-250. https://psycnet.apa.org/record/1943-03624-001

Kolvin, I. (1971). Studies in the childhood psychoses: I. diagnostic criteria and classification. British Journal of Psychiatry, 118(545) 381-384. https://doi.org/10.1192/bjp.118.545.381

Konstantareas, M. M., \& Hewitt, T. (2001). Autistic disorder and schizophrenia: Diagnostic overlaps. Journal of Autism and Developmental Disorders, 31(1), 19-28. https://doi.org/10.1023/a:1005605528309

Kopelowicz, A., Liberman, R. P., \& Zarate, R. (2006). Recent advances in social skills training for schizophrenia. Schizophrenia Bulletin, 32(1), 12-23. https://doi.org/10.1093/schbul/sbl023

Lam, K. S., Aman, M. G., \& Arnold, L. E. (2006). Neurochemical correlates of autistic disorder: A review of the literature. Research in Developmental Disabilities, 27(3), 254-289. https://doi.org/10.1016/j.ridd.2005.03.003

Landa, R., \& Garrett-Mayer, E. (2006). Development in infants with autism spectrum disorders: A prospective study. Journal of Child Psychology and Psychiatry, 47(6), 629-638. https://doi.org/10.1111/j.14697610.2006.01531.x

Le Bihan, D., Breton, E., Lallemand, D., Grenier, P., Cabanis, E., \& Laval-Jeantet, M. (1986). MR imaging of intravoxel incoherent motions: Application to diffusion and perfusion in neurologic disorders. Radiology, 161(2), 401-407. https://doi.org/10.1148/radiology.161.2.3763909

Lewis, S., Escalona, P., \& Keith, S. (2009). Phenomenology of schizophrenia. In B. Kaplan, V. Sadock, \& P. Ruiz (Eds.), Kaplan and Sadock's comprehensive textbook of psychiatry (pp. 1433-1451). Lippincott Williams and Wilkins.

Li, H., Pearrow, M., \& Jimerson, S. R. (2010). Identifying, assessing, and treating early onset schizophrenia at school. Springer.

Liberman, R. P., \& Kopelowicz, A. (2005). Recovery from schizophrenia: A concept in search of research. Psychiatry Services, 56(6), 735-742. https://doi.org/10.1176/appi.ps.56.6.735

McAlonan, G. M., Cheung, V., Cheung, C., Suckling, J., Lam, G. Y., Tai, K. S., Yip, L., Murphy, D. G. M., \& Chua, S. E. (2005). Mapping the brain in autism. A voxel-based MRI study of volumetric differences and intercorrelations in autism. Brain, 128(2), 268-276. https://doi.org/10.1093/brain/awh332 
Meyer, U., Feldon, J., \& Dammann, O. (2011). Schizophrenia and autism: Both shared and disorder-specific pathogenesis via perinatal inflammation? Pediatric Resarch, 69(5), 26-33. https://doi.org/10.1203/PDR.0b013e318212c196

Morgese, G., \& Lombardo, G. P. (2019). 'Dementia praecocissima': The Sante De Sanctis model of mental disorder in child psychiatry in the $20^{\text {th }}$ century. History Psychiatry, 30(3), 300-313. https://doi.org10.1177/0957154X19832776/

Myles-Worsley, M., Weaver, S., \& Blailes, F. (2007). Comorbid depressive symptoms in the developmental course of adolescent-onset psychosis. Early Intervention in Psychiatry, 1(2), 183-190. https://doi.org/10.1111/j.1751-7893.2007.00022.x

National Autism Center. (2009). National standards report, phase 1. https://nationalautismcenter.org/nationalstandards-project/history/

National Autism Center. (2015). Findings and conclusions: National standards project, phase 2. https://www.nationalautismcenter.org/national-standards-project/phase-2/

Nicolson, R., Lenane, M., Hamburger, S. D., Fernandez, T., Bedwell, J., \& Rapoport, J. L. (2000). Lessons from childhood-onset schizophrenia. Brain Research Reviews, 31(2-3), 147-156. https://doi.org/10.1016/S0165-0173(99)00032-6

Olçay-Gül, S., \& Tekin-İftar, E. (2016). Family generated and delivered social story intervention: Acquisition, maintenance, and generalization of social skills in youths with ASD. Education and Training in Autism $\begin{array}{llll}\text { and Developmental } & \text { Disabilities, }\end{array}$ http://www.daddcec.com/uploads/2/5/2/0/2520220/etadd_51_1_.pdf

Osterling, J., \& Dawson, G. (1994). Early recognition of children with autism: A study of first birthday home videotapes. Journal of Autism and Developmental Disorders, 24(3), 247-257. https://doi.org/10.1007/BF02172225

Ozonoff, S., Losif, A., Baguio, F., Cook, I. C., Moore-Hill, M., Hutman, T., Rogers, S. J., Rozga, A., Sangha, S., Sigman, M., Steinfeld, M. B., \& Young, G. S. (2010). A prospective study of the emergence of early behavioral signs of autism. Journal of American Academy of Child \& Adolescent Psychiatry, 49(3), 256266. https://doi.org/10.1016/j.jaac.2009.11.009

Patten, E., Belardi, M. S., Baranek, G. T., Watson, L. R., Labban, J. D., \& Oller, D. K. (2014). Vocal patterns in infants with autism spectrum disorder: Canonical babbling status and vocalization frequency. Journal of Autism Development and Disorders, 44(10), 2413-2428. https://doi.org/10.1007/s10803-014-2047-4

Paul, R., Chawarska, K., Fowler, C., Cicchetti, D., \& Volkmar, F. (2007). Listen, my children and you shall hear: Auditory preferences in toddlers with ASD. Journal of Speech, Language, and Hearing Research, 50(5), 1350-1364. https://doi.org/10.1044/1092-4388(2007/094)

Paul, R., \& Norbury, C. F. (2011). Language disorders from infancy through adolescence: Listening, speaking, reading, writing, and communicating (4th ed.). Elsevier.

Persico, A. M., \& Napolioni, V. (2013). Autism genetics. Behavioral Brain Research, 251, 95-112. https://doi.org/10.1016/j.bbr.2013.06.012

Pinkham, A. E., Hopfinger, J. B., Pelphrey, K. A., Piven, J., \& Penn, D. L. (2008). Neural bases for impaired social cognition in schizophrenia and autism spectrum disorders. Schizophrenia Research, 99(1-3), 164-75. https://doi.org/10.1016/j.schres.2007.10.024

Prelock, P. A., Paul, R., \& Allen, E. M. (2011). Evidence-based treatments in communication for children with autism spectrum disorders. In B. Reichow, P. Doehring, D. V. Cicchetti, \& F. R. Volkmar (Eds.), Evidence-based practices and treatments for children with autism (pp. 93-171). Springer.

Rapin, I., \& Tuchman, R. F. (2008). Autism: Definition, neurobiology, screening, diagnosis. Pediatric Clinics of North America, 55(5), 1129-1146. https://doi.org/10.1016/j.pcl.2008.07.005 

SPECTRUM DISORDERS: A LITERATURE REVIEW

Rapoport, J., Chavez, A., Greenstein, D., Addington, A., \& Gogtay, N. (2009). Autism spectrum disorders and childhood-onset schizophrenia: Clinical and biological contributions to a relation revisited. Journal of the American Academy of Child and Adolescent Psychiatry, 48(1), 10-18. https://doi.org/10.1097/CHI.0b013e31818b1c63

Remschmidt, H., Martin, M., Fleischhaker, C., Theisen, F. M., Hennighausen, K., Gutenbrunner, C., \& Schulz, E. (2006). Forty-two years later: The outcome of childhood-onset schizophrenia. Journal of Neural Transmission, 114(4), 505-512. https://doi.org/10.1007/s00702-006-0553-z

Roth, F. P., \& Worthington, C. K. (2015). Treatment resource manual for speech-language pathology (5th ed.). Cengage Learning.

Rus-Calafell, M., Gutiérrez-Maldonado, J., Ribas-Sabaté, J., \& Lemos-Giráldez, S. (2014). Social skills training for people with schizophrenia: What do we train? Behavioral Psychology, 22(3), 461-477. https://psycnet.apa.org/record/2014-55699-005

Schlosser, R. W., \& Wendt, O. (2008). Effects of augmentative and alternative communication intervention on speech production in children with autism: A systematic review. American Journal of Speech-Language Pathology, 17(3), 212-230. https://doi.org/10.1044/1058-0360(2008/021)

Shenton, M. E., Dickey, C. C., Frumin, M., \& McCarley, R. W. (2001). A review of MRI findings in schizophrenia. Schizophrenia Research, 49(1-2), 1-52. https://doi.org/10.1016/S0920-9964(01)00163-3

Smith, T. (2001). Discrete trial training in the treatment of autism. Focus on Autism and Other Developmental Disabilities, 16(2), 86-92. https://doi.org/10.1177/108835760101600204

Stafford, M. R., Mayo-Wilson, E., Loucas, C. E., James, A., Hollis, C., Birchwood, M., \& Kendall, T. (2015). Efficacy and safety of pharmacological and psychological interventions for the treatment of psychosis and schizophrenia in children, adolescents and young adults: A systematic review and meta-analysis. PLoS One, 10(2), e0117166. https://doi.org/10.1371/journal.pone.0117166

Stefanatos, G. A., \& Baron, I. S. (2011). The ontogenesis of language impairment in autism: A neuropsychological perspective. Neuropsychology Review, 21(3), 252-270. https://doi.org/10.1007/s11065-011-9178-6

Stone, W. L., Ousley, O. Y., Yoder, P. J., Hogan, K. L., \& Hepburn, S. L. (1997). Nonverbal communication in two- and three-year-old children with autism. Journal of Autism and Developmental Disorders, 27(6), 677-696. https://doi.org/10.1023/a:1025854816091

Tager-Flusberg, H., \& Anderson, M. (1991). The development of contingent discourse ability in autistic children. $\begin{array}{llllll}\text { Journal of Child Psychology and Psychiatry, } & 32, & 1123-1134 .\end{array}$ https://doi.org/10.1111/j.1469-7610.1991.tb00353.x

Thaker, G. (2009). Schizophrenia: Phenotypic manifestations. In B. J. Sadock, V. A. Sadock, \& P. Ruiz (Eds.), Kaplan and Sadock's comprehensive textbook of psychiatry (pp. 1541-1547). Lippincott Williams and Wilkins.

Toal, F., Bloemen, O. J., Deeley, Q., Tunstall, N., Daly, E. M., Page, L., Brammer, M. J., Murphy, K. C., \& Murphy, D. G. M. (2009). Psychosis and autism: Magnetic resonance imaging study of brain anatomy. British Journal of Psychiatry, 194(5), 418-425. https://doi.org/10.1192/bjp.bp.107.049007

Töret, G., \& Acarlar, F. (2011). Gestures in prelinguistic Turkish children with autism, Down syndrome, and typically developing children. Educational Sciences: Theory \& Practice, 11(3), 1471-1478. https://files.eric.ed.gov/fulltext/EJ936327.pdf

Trevisan, D. A., Foss-Feig, J. H., Naples, A. J., Srihari, V., Anticevic, A., \& McPortland, J. C. (2020). Autism spectrum disorder and schizophrenia are better differentiated by positive symptoms than negative symptoms. Frontiers in Psychiatry, 11(548), 1-10. https://doi.org/10.3389/fpsyt.2020.00548

Volkmar, F. R., Carter, A., Grossman, J., \& Klin, A. (1997). Social development in autism. In D. J. Cohen \& F. R. Volkmar (Eds.), Handbook of autism and pervasive developmental disorders (pp. 173-194). Wiley.

Vyas, N. S., \& Gogtay, N. (2012). Treatment of early onset schizophrenia: Recent trends, challenges and future considerations. Frontiers in Psychiatry, 3(29), 1-5. https://doi.org/10.3389/fpsyt.2012.00029 
Wallace, C. J., \& Lieberman, R. P. (1985). Social skills training for patients with schizophrenia: A controlled clinical trial. Psychiatry Research, 15(3), 239-247. https://doi.org/10.1016/0165-1781(85)90081-2

Waterhouse, L., \& Fein, D. (1984). Developmental trends in cognitive skills for children diagnosed as autistic and schizophrenic. Child Development, 55(1), 236-248. https://doi.org/10.2307/1129848

Wetherby, A. M., Woods, J., Allen, L., Cleary, J., Dickinson, H., \& Lord, C. (2004). Early indicators of autism spectrum disorders in the second year of life. Journal of Autism and Developmental Disorders, 34(5), 473-493. https://doi.org/10.1007/s10803-004-2544-y 


\section{Ankara Üniversitesi Eğitim Bilimleri Fakültesi Özel Eğitim Dergisi}

2022, 23(3), 655-673
DERLEME

Gönderim Tarihi: 03.07.20

Kabul Tarihi: 21.07.21

Erken Görünüm: 25.09.21

\section{Çocukluk Çağı Başlangıçıı Şizofreni ve Otizm Spektrum Bozukluğunda Dil ve İletişim Özellikleri: Bir Literatür Taraması}

\author{
Tuğçe Çabuk ${ }^{(i)} 1$
}

\author{
Şevket Özdemir ${ }^{(i D} 2$
}

Gökhan Töret ${ }^{\mathrm{D} 3}$

$\ddot{O} z$

Giriş: Şizofreni (ŞZ) ve otizm spektrum bozuklukları (OSB) bireyler üzerinde yaşam boyu olumsuz etkilere sahiptir. Çocukluk çağı başlangıçlı şizofreni (ÇÇBŞ), OSB'nin aksine çocuklukta (13 yaşından önce) "nadiren" ortaya çıkan bir ŞZ türüdür. ÇÇBŞ ve OSB farklı bozukluklar olmasına rağmen, ilk tanımlandıkları andan itibaren iki bozukluğun birtakım ortak özelliklerinin olduğu ifade edilmektedir. En önemli ortak noktalardan biri, örtüşen dil ve iletişim özellikleridir. Şimdiye kadar, bu iki bozukluğun her ikisini de kapsayan dil özellikleri ile bu özelliklerin altında yatan nörogenetik faktörlere ilişkin bütünleştirici bir model ortaya konmamıştır. Bu literatür taraması çalışması iki popülasyona ait farklı ve ortak dil sorunlarını ortaya çıarmayı ve önceki araştırma bulgularını sunmayı amaçlamıştır. Ayrıca, çalışmada sunulan bilgilerin özel eğitim uzmanlarının ÇÇBŞ belirtileri gösteren çocukları fark etmelerine yardımcı olması beklenmektedir. Bu doğrultuda öncelikle, bozuklukların tarihsel geçmişinden bahsedilmiştir. Sonrasında ÇÇBŞ ve OSB'nin dil ve iletişim özelliklerine odaklanılmıştır ve örtüşen özellikler sunulmuştur.

Tartışma: Geçmiş çalışmalardan hareketle, her iki popülasyonda da dilin kullanım boyutuna yönelik sınırlılıkların gözlenebileceği sonucuna varılmıştır. Ekolali ve kendi kendine konuşma gibi atipik dil özelliklerinin de görülebileceği belirtilmiştir. Bu bağlamda, ÇÇBŞ ve OSB'nin biçimbilgisel ve anlambilgisel düzeylerini araştıran çalışmalar desenlenebileceği, büyük bir örneklem grubu üzerinden geçmişe ve ileriye dönük çalışmalara gereksinim duyulduğu ifade edilmiştir. Dil ile hayali oyun veya yürütücü işlevleri arasındaki bağlantının incelenmesinin önemi vurgulanmıştır.

Anahtar sözcükler: Çocukluk çağı başlangıçlı şizofreni, otizm spektrum bozukluğu, dil, iletişim, şizofreni.

Atıf için: Çabuk, T., Özdemir, Ş., \& Töret, G. (2022). Çocukluk çağı başlangıçlı şizofreni ve otizm spektrum bozukluğunda dil ve iletişim özellikleri: Bir literatür taraması. Ankara Üniversitesi Eğitim Bilimleri Fakültesi Özel Eğitim Dergisi, 23(3), 655-673. https://doi.org/10.21565/ozelegitimdergisi.857651

${ }^{1}$ Uzman Dil ve Konuşma Terapisti, Doktora Öğrencisi, İhsan Doğramac1 Bilkent Üniversitesi, E-posta: tugce.cabuk@bilkent.edu.tr, https://orcid.org/0000-0003-1881-1349

${ }^{2}$ Sorumlu Yazar: Dr. Öğr. Üyesi, Muğla Sitk1 Koçman Üniversitesi, E-posta: sevketozdemir@mu.edu.tr, https://orcid.org/0000-0002-1230-6491

3ㅁ. Öğr. Üyesi, Hacettepe Üniversitesi, E-posta: gokhan.toret@hacettepe.edu.tr, https://orcid.org/0000-0001-8801-2310 


\section{Giriş}

Şizofreni (ŞZ) ve Otizm Spektrum Bozukluğu (OSB) birey üzerinde yaşam boyu olumsuz etki oluşturur. Ruhsal Bozuklukların Tanısal ve İstatistiksel El Kitabi'nda (Diagnostic and Statistical Manual of Mental Disorders [DSM-V]) nöropsikiyatrik bir bozukluk olan ŞZ'li bireyi tanılama ölçütlerinin birden çok boyutu vardır (American Psychiatric Association [APA], 2013). ŞZ, "çoğunlukla" geç ergenlik ve erken dönem yetişkinlikte başlar; sosyal ve mesleki bozulmalara neden olan halüsinasyon, sanrı, dağınık düşünce ve dil bozukluğu gibi kalıcı belirtilerle kendini gösterir. Çocukluk Çağı Başlangıçlı Şizofreni (ÇÇBŞ) ise çocuklukta (genellikle 13 yaşından önce) "nadiren" ortaya çıkar (Remschmidt vd., 2006). Öte yandan nörogelişimsel bir bozukluk olan OSB; sosyal iletişimde belirgin sınırlılıklar ile tekrarlayan etkinlikler, davranışlar ve ilgiler gibi belirtilerle tanımlanmaktadır (APA, 2013). Farklı tanı grupları olmalarına rağmen; ÇÇBŞ ve OSB'nin, ilk tanımlandıkları zamandan itibaren davranışsal ve bilişsel yönden ortak özellikleri olduğu ifade edilmektedir. Bu ortak özellikler arasında genetik ve çevresel faktörler, sosyal biliş, düşünce, dil ve iletişim bozuklukları, nörobiyolojik ve nörofizyolojik özelliklerden oluşan beyin anormallikleri ve bozuklukların klinik belirtileri bulunmaktadır (Barlati vd., 2016). Bu derlemede; (i) ÇÇBŞ ve OSB'deki dil ve iletişim özellikleri, (ii) iki gruptaki ortak dil ve iletişim özellikleri ile (iii) ileriye dönük çalışmalar ve müdahaleye ilişkin öneriler sunulması planlanmaktadır.

ŞZ ve OSB, tanısal kafa karışıklığıyla dolu uzun bir geçmişe sahiptir (Konstantareas \& Hewitt, 2001; Rapoport vd., 2009). Emil Kraepelin, 1800'lerin sonlarında ŞZ olarak da bilinen "demans praecox"u ilk ortaya çıkardığında, bilişsel bozukluklarla bağlantılı nörodejeneratif hastalıkları "epizodik afektif bozukluklardan" (ör. manik depresyon) ayırt etmeyi başarmıştır (Ebert \& Bar, 2010). Daha sonra Sante de Sanctis, "demans praecox"u çocukluk psikiyatrisi alanına kazandırarak, tanıma psikotik durumlar ve otizm gibi çocukluk belirtilerinin birlikte görüldüğü "demans praecocissima" adını vermiştir. Bu semptomların mevcut literatürde karakter tuhaflığı, ilgisizlik, depresif ruh hali, halüsinasyon ve katatoniye işaret ettiği bilinmektedir (Morgese \& Lombardo, 2019). Otizm başlangıçta ayrı ve farklı ele alınmamıştır. Tam tersine, Bleuler otizmin ŞZ semptomlarını sergileyen bir bozukluk olduğunu öne sürmüştür (Bleuler, 1950). OSB'yi ayrı bir patoloji olarak kategorize eden DSM-III'ün piyasaya sürülmesinden önce OSB, anormal gerçeklik algısı ve sosyal işlevsellik özellikleri taşıyan bir ÇÇBŞ olarak teşhis edilmiştir (APA, 1952, 1968; Grinker, 2008). Ayrıca, nadir ve şiddetli bir OSB çeşidi olarak bilinen Heller sendromu veya (başka bir deyişle) gelişimsel gerileme ile karakterize çocukluk çağı dezintegratif bozukluğu, genellikle paranoya ve psikoz ile ilişkilendirilmiştir (Trevisan vd., 2020). Benzer şekilde, halüsinasyon ve sanrı örnekleri Asperger sendromunda bildirilmiştir (Arora vd., 2011; Jansch \& Hare, 2014). Bu sendromlar artık DSM-V'te (APA, 2013) OSB altında olsa da, bu öneriler OSB ve ŞZ semptomlarının örtüşebileceğini göstermesi bakımından önemlidir (Trevisan vd., 2020).

Mevcut çalışmalar birbiriyle örtüşen ancak tutarsız bulgular sunmaktadır (Meyer vd., 2011). Davranışsal düzeyde sosyal biliş, gecikmiş dil, yürütücü işlevler, duygusal işlemlemede bozulmalar, psikopatolojik özellikler açısından sorunlar gözlenmiştir (Cheung vd., 2010; Rapin \& Tuchman, 2008). Ayrıca, beyin morfolojik düzeyi ile ilgili geçmiş çalışmalar, bu bozuklukların her ikisinde de serebellum, insular korteks, fusiform girusta yapısal ve işlevsel anormallikler bildirmiştir (Cheung vd., 2010; McAlonan vd., 2005; Shenton vd., 2001; Toal vd., 2009). ŞZ ve OSB'li bireyler, sosyal bilişle ilişkili becerilerde düşük performans gösterdikleri için fMRI çalışmalarında fusiform girus, sağ amigdala ve ventrolateral prefrontal kortekste azalmış aktivasyon saptanmıştır (Pinkham vd., 2008). Bir meta-analiz çalışması, ilgili bozukluklara sahip çocuklar üzerinde gerçekleştirilen beyin görüntüleme çalışmalarından elde edilen bulgular çerçevesinde yapısal bir uyumun söz konusu olabileceğini göstermiştir (Cheung vd., 2010). Bu uyuma özgü yapısal alanlar, sağ parahipokampal girus, putamen, arka singulat, klostrum ve sol talamusu içermektedir (Cheung vd., 2010). Hücresel düzeyde, her iki bozuklukta da değişime uğrayan en bilinen nöronal belirteçin Reelin olduğu belirtilmektedir (Fatemi, 2005). Reelin, erken nörogelişimsel aşamalarda oldukça etkili olmakla birlikte "göç eden hücre için bir ayrılma sinyali" sağlaması yönündeki işlevi ile bilinmektedir. Azalmış Reelin'in ŞZ ve OSB'li çocuklarda nörogelişimsel gecikmeye katkıda bulunabileceği bilinmektedir (Fatemi, 2005). Nörokimyasal düzeyde, bu bozukluklarda serotonerjik sistemle ilgili eksiklikler olabilmektedir. (Abi-Dargham vd., 1997; Lam vd., 2006). Son olarak, doğum öncesi enfeksiyon ve stres öyküsü, ebeveyn yaşı ile CNTNAP2 ve NRXN1 gibi genlerle ilişkili çevresel ve genetik etkenlerin ŞZ ve OSB'yi etkilediği düşünülmektedir (Barlati, 2016; Meyer vd., 2011). Özetle, tarihsel arka planına bakıldığında, keşfedildiği dönemden bu yana dil alanındaki sorunlar bakımından davranışsal araştırmalar benzerlikler olabileceğine işaret etmiştir. Bazı beyin ve genetik araştırmalar bu bakış açısını desteklemektedir. Ancak bazı araştırmalar ortak dil sorunlarına rağmen, farklılaşan dil sorunlarına da işaret etmiştir. Dolayısıyla her iki bozukluk ile ilgili ortak dil bozuklukları ve altında yatan nörogenetik faktörlere ilişkin bütüncül bir model sunan bakış açısı bulunmamaktadır. $\mathrm{Bu}$ nedenle, bu derleme çalışmasında ortak dil sorunları ve farklı dil sorunları araştırmalar özelinde ele alınarak 
tartışılacaktır. Ayrıca, özel eğitim uzmanlarının ÇÇBŞ belirtileri gösteren çocukları fark etmelerine yardımcı olması amaçlanacaktır. Bu sayede, uzmanların psikiyatrik değerlendirme için çocukları yönlendirmeleri, ayırıcı tanılarına ve uygun müdahale programlarından faydalanmalarına katkıda bulunmaları beklenmektedir.

\section{Çocukluk Çağı Başlangıçı Şizofrenide Temel Dil ve İletişim Özellikleri}

ÇÇBŞ, ŞZ’nin nadir ve daha şiddetli bir türü olarak görülmektedir (Hart \& Lewine, 2017). "Formal Düşünce Bozukluğu" veya "ŞZ'de dil ve iletişim bozuklukları", ÇÇBŞ'deki temel klinik belirtilerden biridir (Hart \& Lewine, 2017). FDB/DB, "organizasyon, kontrol, işlemleme veya düşüncelerin ifadesi dahil olmak üzere düşünme biçimini etkileyen bir rahatsızlık" olarak tanımlanabilir (Hart \& Lewine, 2017). Klinik belirtiler arasında mantıksız düşünme, tutarsızlık, konuşmada bağlam kopuklukları (raydan çıkma) ve zengin olmayan konuşma içeriği yer alır (APA, 2013). Bu işaretler, bilişsel ve dilbilimsel becerilerinin bozulması sonucu ortaya çıkan FDB'yi de tanımlar (Caplan, 1994). Ek belirtiler arasında raydan çıkma, teğetsellik (söylemle ilgili olmayan diğer konular hakkında konuşma eğilimi), çevresellik (konuşmayı gereksiz ve ilgisiz ayrıntılarla doldurmak, ana noktaya ulaşmada zorluklarla karşılaşmak), ekolali ve perseverasyon olarak sıralanabilir (Andreasen, 1979).

Günümüze kadar az sayıda çalışma (Arbodela \& Holzman, 1985; Cantor vd., 1982; Caplan, 1994; Kolvin, 1971) ÇÇBŞ’ye özgü dil ve iletişim özelliklerini incelemiştir. Bu çalışmalar ŞZ'li çocukların raydan çıkma (Arbodela \& Holzman, 1985), neolojizm ("mersku" gibi yeni bir kelime yaratma) (Cantor vd., 1982), uyaklı çağrışım (kavramdan ziyade kelimelere ait seslere dayanarak konuşma yapısını oluşturma) (Arbodela \& Holzman, 1985; Cantor vd., 1982), mantıksızlık (Cantor vd., 1982; Caplan, 1994), zengin olmayan konuşma içeriği (Caplan, 1994) gibi belirtiler sergilediğini göstermiştir. ÇÇBŞ'de özellikle pragmatik ve söylemle ilgili sorunlar gözlenmiştir (Caplan, 1994). Özellikle ŞZ'li çocuklar, tipik gelişim gösteren akranlarına kıyasla daha az sayıda sözce (utterance) üretmektedir. Sözceler arasında yeterli sayıda yapısal bağlantıyı sağlayacak öğelerin bulunmadığı saptanmıştır. ÇÇBŞ'li çocuklar yine bu sözceler arasında daha önce bahsedilen insanlara, nesnelere ve olaylara yeterince gönderim (reference) yapmamışlardır (Caplan, 1994; Caplan vd., 1992). Bu durum bağlamda kopukluklara neden olmuş ve gönderimler belirsiz olduğundan dinleyicilerin kafasını karıştırmıştır (Harvey \& Brault, 1986). Dahası ŞZ'li çocuklar tipik gelişim gösteren çocuklara göre daha az birleşik cümlecikler (contiguous clauses) (örneğin; Tuğçe markete gitti. Sarımsak aldı) ve sözcüksel bağlaşıklık (lexical cohesion) olarak bilinen tekrarlanan kelimeler veya kelime kökleri üretmişlerdir. Ayrıca, dinleyicinin konuşacakları konu hakkındaki bilgiye halihazırda sahip olduğunu düşündüklerinden konuşmaları sırasında bazı bilgileri atmışlardır (eksilti, ellipsis). Sözdizimsel karmaşıklık açısından basit cümleler kullanmışlardır. Bu sebepten, dinleyiciler ŞZ'li çocukların konuşmalarını anlamakta ve cümleler arasında bağlantı kurmakta zorlanmışlardır (Caplan, 1994). Baltaxe ve Simmons (1988) ÇÇBŞ'de yukarıda belirtilen eksikliklerle ilgili bir sınıflama önermiştir: (1) Gönderimde bulunma (dinleyicilere bağlama dair yeterli bilgi sağlamadaki eksiklik, uygun olmayan gönderimler arasında geçiş yapma, eski ve yeni bilgi arasındaki bağlantıyı anlayamama ve eksilti kullanma); (2) geçiş yapma (Konuya bağlamsal açıdan uygun olmayan bir konu ekleyerek genişletme ve bağlamı kendi sunduğu konuya çevirme/çekme); (3) söylemi sıralama (bir olayı açıklarken uygun ve mantıksal ifadeleri hatırlama ve sıralamada zorluk yaşamak) ve (4) sıra alma sorunları. ŞZ hastalığı olan çocukların dildeki soyut kavramları anlamada güçlük çektikleri görülmüştür. Ayrıca duraklamalar gibi konuşma akıcılığında sorunlar gözlenmiştir. Bu sorunların dilin kullanım boyutuyla ilişkilendirilebileceği öne sürülmüştür (Baltaxe \& Simmons, 1995). ŞZ hastalığı olan çocuklar tipik gelişen akranlarına göre daha düşük alıcı ve ifade edici sözcük puanlarına sahip oldukları için (Waterhouse \& Fein, 1984; Fish, 1987), kelime dağarcı̆̆ı ile ilgili sorunların olduğu belirtilmiştir (Baltaxe \& Simmons, 1995). Yetişkinlik döneminde ŞZ'de görüldüğü gibi, ŞZ'li çocuklar konuşurken duygusal sığlaşma (affective flattening) gibi bürünsel sorunlar yaşamıştır (Baltaxe \& Simons, 1995).

\section{Otizm Spektrum Bozukluğunda Temel Dil ve İletişim Özellikleri}

Nörogelişimsel bir bozukluk olan OSB tanısının, 3 yaşından önce üç temel belirti çerçevesinde konduğu belirtilmektedir: (a) Sosyal etkileşim ve (b) dil alanlarında belirgin hasarlanma, ile (c) Günlük yaşam rutinlerinde önemli sorunlara neden olan stereotipik davranışlar (APA, 2013). Bu çerçevede OSB sosyal etkileşim, sembolik oyun, sözel ve sözel olmayan iletişim alanlarında güçlüklerle karakterize edilmektedir. Bu alanlarda etkilenme şiddetine göre sınıflanmaktadır (DSM-V; APA, 2013). DSM-V'in tanı kriterlerinde ifade edilen iki temel belirtinin yanında dil sorunlarının da tanılama sürecine dahil edilmesi gerektiği vurgulanmaktadır. Otizmli çocukların yaklaşık yarısının işlevsel herhangi bir sözel çıktısının olmayabileceği belirtilmektedir (Prelock vd., 2011). Sözel çıktıları olan OSB'li çocukların sözdizimi gelişimi bakımından dilin kurallarına uygun cümle üretiminde ciddi sıkıntı yaşadıkları vurgulanmaktadır (Roth \& Worthington, 2015). Dil gelişim basamaklarında gecikmeden ziyade 
“sapma ya da anormallik” (İng. “aberrant”) görüldüğü ifade edilmektedir. OSB’li çocukların dil gelişim profilinin heterojen olduğu belirtilmektedir (Paul \& Norbury, 2011; Roth \& Worthington, 2015).

OSB'de söz öncesi iletişimde altı önemli özellik olduğu gözlenmektedir: Atipik vokalizasyon (Patten vd., 2014), işaret etmede gecikme (Dawson vd., 1998; Stone vd., 1997), ismine tepki vermeme (Osterling \& Dawson, 1994; Paul vd., 2007), başkalarının eylemleri ya da vokalizasyonlarını taklit etmede sınırlılık (Volkmar vd., 1997), ortak dikkat oluşturamama (Paul \& Norbury, 2011; Töret \& Acarlar, 2011). Bu özellikler OSB'li çocukların söz öncesi dönemden sonraki basamaklara geçmede sorun yaşadığını göstermektedir. Başka bir deyişle, bu sorunlar sonraki basamaklarda gözlenen sözcük dağarcığının, sözcüklere eklemlenen yapıların ve tüm bunların uygun dilsel bağ lamlarda kullanımına ilişkin çabaların sınırlı olmasına sebep olmaktadır. Aynı zamanda, bu özelliklerin OSB'li çocukları gelişimsel dil bozukluğu olan çocuklardan ayırt edebildiği belirtilmektedir (Gabrielsen vd., 2015; Landa \& Garrett-Mayer, 2006; Wetherby vd., 2004).

İki yaş sonrasında OSB'li çocuklar dil ve iletişim açısından ciddi sorunlar yaşamaya devam ederler. Öncelikle, tek sözcük ediniminde gecikme veya tek sözcükten ikili ya da çoklu sözcük kombinasyonuna geçmede sorun yaşarlar. Tek sözcük ediniminde gecikme sözcük dağarcığındaki ilerlemenin yavaş olmasını düşündürmektedir. Bu edinim gerçekleşmesine rağmen, ikili ya da çoklu sözcük kombinasyonlarına geçişte yaşanan sorun, OSB'li çocukların semantik açıdan birbiriyle ilişkili sözcükler arasındaki bağı öğrenmede sıkıntı yaşamasına bağlanmaktadır (Eigsti vd., 2011; Kamio vd., 2007). Ayrıca; taklit, göz kontağı ve ortak dikkat ile jest-mimik kullanımında sorun yaşamaya devam etmektedirler. Bu durum, özellikle herhangi bir iletişim girişiminde bulunmak istememe ya da başkalarının girişimlerine kayıtsızlık şeklinde kendini göstermektedir (Tager-Flusberg \& Anderson, 1991; Roth \& Worthington, 2015). Üçüncü olarak, empati sorunu ile birlikte duygulara ilişkin sözcükleri anlama ve ifade etmede sorun yaşamaktadırlar. Bu durum, uyaranlara uygun yanıtı vermede yaşanabilecek sorunları da tetiklemektedir (Roth \& Worthington, 2015). Bununla birlikte, sıra dışı bir şahıs zamiri kullanım özelliği olarak kendilerinden üçüncü bir kişi gibi söz ettikleri gözlenmektedir (Eigsti \& Bennetto, 2009). Son olarak, OSB'li çocuklarda yaygınlıkla gözlenen ekolalinin dil gelişimi üzerinde olumsuz etkisi olduğu ifade edilmektedir (Paul \& Norbury, 2011; Prelock vd., 2011; Roth \& Worthington, 2015).

\section{Tartışma}

\section{Cocukluk Çağı Başlangıçlı Şizofreni ve Otizm Spektrum Bozukluğundaki Dil ve İletişim Özellikleri Örtüşüyor mu?}

ÇÇBŞ ve OSB'de gözlenen dil ve iletişim sorunlarının ortak olabileceği düşünülmektedir. Konuşma organizasyonundaki sorunlara odaklanıldığında, düşüncelerin birbirinden kopuk olması göze çarpmaktadır. OSB'li bireyler birbiriyle ilişkili olmayan sözceleri az sayıda üretirken, bu sözcelerin iletişim akışına uygun olmadığı ifade edilmektedir (Stefanatos \& Baron, 2011). İlginç bir şekilde bu konuşma örüntülerinin ÇÇBŞ’de de gözlendiği belirtilmektedir. SZ'li çocuklar bağlam içerisinde ifadeler arasında ilişki kuramamakta, konuları birinden diğerine hızlıca değiştirmekte, tekrarlayan ifadeleri sıklıkla kullanmakta ve herhangi bir anlamı olmayan sözcükleri üretmektedirler (Alary vd., 2013).

Lewis ve diğerleri (2009) zengin bir içeriği olmayan konuşma örüntüsü ile sorulara hızlı ve yüzeysel yanıt verme özelliklerinin hem Asperger sendromu (yüksek işlevli otizm spektrum bozukluğu) hem de ÇÇBŞ'de gözlenebileceğini ifade etmektedir. Ayrıca, her iki bozuklukta da neolojistik üretim ve ekolali görülebilir (Fitzgerald, 2012). Sohbet sırasında fazla ya da gerekli olmayan detaylar verdikleri gözlenebilir (Fitzgerald, 2012; Thaker, 2009).

Klinik pratikte tanısal açıdan kafa karışıklığı yaratan iki önemli nokta bulunmaktadır: Sosyal iletişim ve sosyal-duygusal alışverişte zorluklar. İlişkili zorluklar duygu paylaşımında isteksizlik, göz kontağının eksikliği ya da yetersizliği, yüz ifadeleri ile jestlerin sınırlı kullanımı ve spontan iletişimi başlatmadaki sıkıntıları içermektedir (Barlati vd., 2016; Fitzgerald, 2012; Trevisan vd., 2020). Bu iki popülasyonda gözlenen sorunların ortak sinirsel kaynaklarının olabileceği ifade edilmiştir. $\mathrm{Bu}$ doğrultuda beyin görüntüleme çalışmaları ilgili bozukluklarda prefrontal korteks, sağ amigdala, fusiform face bölgesinde azalmış aktivasyon tespit etmiştir. Bu aktivasyonun her iki popülasyonda da sosyal iletişim problemleri ile sonuçlanabileceği ifade edilmiştir (Pinkham vd., 2008; Couture vd., 2010). Ancak, bu gibi ortak özelliklerin yanında farklı olabilecek özelliklerin de söz konusu olabileceği savunulmuştur. Bu doğrultuda, Trevisan ve diğerleri (2020) yaşları 18-48 arasında değişen 39 ŞZ'li ve 53 OSB'li bireyi çalışmalarına dahil etmiştir. İki bozukluk arasındaki ortak ya da birbirinden ayrılan özellikleri ortaya çıkarmak için Otizm Tanısal Gözlem Programı'nı (Autism Diagnostic Observation Schedule-2 [ADOS-2]) kullanmışlardır. Bozukluğa özgü özellikler incelendiğinde; ŞZ’li bireylerde halüsinasyon, sanrı ve kendi kendine 
konuşma gibi davranışlar gözlenmiştir. OSB'li bireylerde de ekolali ve atipik sosyal davranışların varlı̆̆ı belirlenmiştir (Trevisan vd., 2020). Bozukluğa özgü özelliklerin bir arada görülebileceği de ifade edilirken; eskiye nazaran daha sık rastlanan bu durumun (Foss-Feig, 2019) iki tanıya da birden götürebileceği savunulmuştur. ADOS-2 formu içinde 11 maddenin puanlaması ile ilgili ek bilgi sunulmuştur: Örneğin, göz kontağı ile ilgili maddede OSB'li bireylerin göz kontağı sergilemediği belirtilirken, SZ'li bireylerde bu durumun "uzun süre anlamsız bakmak" şeklinde kendini gösterdiği ifade edilmiştir (Trevisan vd., 2020).

Hem OSB hem SZ'de ortak dil sorunları genel olarak dil gelişimi gecikmesi ve sıra dışı özelliği olarak sıralanabilir. Dil gelişimi gecikmesi dilin temel bileşenleri açısından bakıldığında her iki grupta özellikle dilin kullanım sınırlılıkları gözlenebilmektedir (örneğin, iletişim amacına uygun jest, sözcük, vb kullanımı). Her iki grupta ekolali veya kendi kendine konuşma gibi atipik dil özellikleri gözlenebilmektedir. Ancak dilin biçim ve semantik alanlarında ortak dil sorunları ile ilgili geçmiş araştırmalar sınırlıdır (Baltaxe \& Simmons, 1995; Fish, 1987; Waterhouse \& Fein, 1984). Son 30 yıldan bu yana yapılan araştırmalar ortak biçim özellikleri arasında sınırlı üretici sözcük dağarcığı gibi gecikmeli bir dil seyrine işaret etmektedir. Bunun yanında, özellikle otizmde dilin heterojen doğası göz önüne alındığında, ortak biçim ve semantik sorunları olduğu önermesini getirmek araştırmalardaki örneklem grubu çeşitliliği, veri toplama araçları farklılıkları gibi araşıırma sınırlılıkları nedeniyle spekülatif bir yorum olacaktır. Dolayısıyla kapsamlı dil unsurlarını içeren gelecek karşılaştırma araştırmalarına gereksinim duyulduğu ortadadır.

\section{İleriye Dönük Araştırmalar için Öneriler}

OSB ve ÇÇŞB, tanıdan müdahaleye klinik ve uygulamalı bilimlerde güncel araştırmaların hızlı değişim gösterdiği bozukluk grupları olarak öne çıkmaktadır. Dil ve sosyal iletişim gelişimi her iki grupta da ortak bir sorun alanı olmakla birlikte uygulamacılar için bilimsel dayanaklı müdahale seçiminde ÇÇŞB'ye göre OSB'nin avantajlı olduğu söylenebilir. Son 15 yıldır OSB'de birçok müdahale araştırmasının belirli ölçütlere göre incelenmesi yoluyla oluşturulan kanıta dayalı uygulama raporları bulunmaktadır (National Autism Center, 2009, 2015). Ancak ÇÇBŞ'de dilin müdahalesinde uygulamacılara rehberlik edecek benzer türde raporlar bulunmamaktadır. Bunun en temel sebebi, ÇÇBŞ tanısının çocukluk dönemde sabit olmaması ile ilgilidir (Trevisan vd., 2020). Çocuk psikiyatrisi ile ilgili düzenli aralıklarla gerçekleşecek bilgi alışverişi, ÇÇBŞ’nin klinik ve eğitsel seyrini tayin etmede büyük katkılar sunacaktır. ÇÇBŞ'ye OSB'nin yanında dikkat eksikliği ve hiperaktivite bozukluğu, öğrenme güçlüğü gibi farklı tanı grupları eşlik edebilmektedir. Ayrıca, kaygı ve depresyon düzeylerinin yüksek olmasından dolayı akademik performans olumsuz yönde etkilenebilmektedir (Chen vd., 2017; Li vd., 2010). Dolayısıyla gelecek araştırmalarda dil özellikleri (örneğin, dilin kullanımında iletişim işlevleri) ve dil ile ilişkili sözel olmayan sosyal iletişim gelişimleri (örneğin, taklit) ve akademik yeterliliklerin (örneğin, okuduğunu anlama) iki grupta karşılaştırılması ve OSB'de dilin müdahalesinde kanıta dayalı olan odaklı müdahale yöntemlerinden genişletilmiş çevresel dil öğretimi (enhanced milieu teaching; Hancock \& Kaiser, 2002) gibi yöntemlerin dil gelişiminin ilerletilmesinde etki düzeylerinin karşılaştırılması önerilmektedir. Diğer yandan bu iki grup, müdahale yaklaşımları bakımından farklılıklar gösterebilmektedir. OSB'de birincil müdahale yerleşik olarak eğitsel müdahale uygulamalarını içermektedir. Bu müdahaleler, uygulamalı davranış analizine dayalı yöntemler (Smith, 2001), doğal, davranışsal ve gelişimsel odaklı müdahaleler (Hancock \& Kaiser, 2002) ve alternatif iletişim yöntemleri (Schlosser \& Wendt, 2008) olarak gruplandırılabilir. Ancak, ÇÇBŞ’de birincil müdahale farmakolojik tedaviyi içermektedir. İkincil müdahale psikososyal müdahale yaklaşımlarını dahil etmektedir: Aile müdahalesi ve sosyal beceri eğitimi. Ancak bu yaklaşımların ağırlıklı olarak SZ'li yetişkin bireylerde uygulandığı ve etkililiğinin sınandığı ifade edilmektedir. Bu sebeplerden, müdahale süreçlerinde kullanılacak farklı yöntemlerin bir arada kullanılacağı kapsamlı ve bütüncül bir yaklaşımın benimsenmesi gerektiği belirtilmektedir. Aile müdahalesi ebeveynlerin etkin katılımını gerektirmektedir. Ailelerin problem çözme ve psiko-sosyal becerilerini arttırmayı hedeflemektedir. Ayrıca, ilaçların yan etkileri, ÇÇBŞ’li bireyin özelliklerine uygun akademik destek programlarına ulaşım ve ÇÇBŞ'li birey ile iletişim konularında bilgi vermeyi amaçlamaktadır (Kopelowicz vd., 2006; Li vd., 2010). Diğer müdahale sosyal beceri eğitimini kapsamaktadır. Benzer şekilde, yetişkinlerde kullanılan sosyal beceri eğitiminin daha küçük yaştaki bireylerin özelliklerine göre uyarlanması önerilmektedir. Sosyal beceri eğitiminin özellikle göz kontağı, konuşmanın içeriği, sohbete dahil olma ve sosyal uyum düzeylerinde olumlu etkilere sahip olabileceği savunulmuştur. Problem durumu, hedef belirleme, rol yapma, olumlu dönüt, sosyal yönden model olma, davranışsal uygulama, olumlu sosyal pekiştirme, ev ödevleri adımlarını içermektedir (Kopelowicz vd., 2006; Li vd., 2010; Rus-Calafell vd., 2014). OSB'de olduğu gibi (Olçay-Gül \& Tekin-İftar, 2016) SZ'li bireylerin sosyal becerileri öğrenmesi, sürdürmesi ve farklı ortamlara genellemesi amaçlanmaktadır (Kopelowicz vd., 2006; Li vd., 2010; Rus-Calafell vd., 2014). Gelecek araştırmalarda iki grupta, 
özellikle dil ile ilişkili sosyal becerilerin güçlendirilmesinde müdahale uygulamalarının etki düzeylerinin karşılaştırılarak incelenmesi önerilmektedir.

Öncesinde de belirtiltiği üzere, yetişkin SZ’li popülasyon için önerilen ve kanıt temeli olan müdahale yaklaşımlarına yönelik gelişimsel bir uyarlama önerilmektedir (Li vd., 2010). Buna ek olarak, ÇÇBŞ’ye kıyasla kanıt temeli çok daha sağlam olan OSB'deki müdahale çalışmalarından faydalanılabileceği önerilebilir. Gelecek araştırmalarda, geniş örneklemde gelişim düzeyleri eşitlenerek ÇÇBŞ ile OSB'nin dil özellikleri karşılaştırılarak incelenebilir. Ayrıca gelecek araştırmalarda otizmde dil sorunlarının erken dönemde gelişimsel izleri ilgili yerleşik bir literatür olduğu göz önüne alındığında, ÇÇBŞ ve OSB'de retrospektif olarak tanı öncesi dönemde, söz öncesi iletişimin gelişmeye başladığı dönemdeki dil sorunları incelenebilir. Bu sayede iki geniş ve kapsamlı bir dil profili ortaya çıarılabilir. Bu iki grubun dil profillerinin daha iyi anlaşılması, OSB'de yerleşik dil müdahale uygulamalarının, ÇÇBŞ'de dil düzeyleri üzerinde etki düzeylerini inceleyecek deneysel araştırmalar için de motivasyon oluşturacaktır. Diğer yandan nitel olarak ÇÇBŞ ve OSB'li çocuğa sahip ebeveynlerin, günlük rutinlerinde çocuklarında gözledikleri iletişim güçlükleri hakkında görüşleri karşılaştırılabilir. Her iki grupta, çocukluk döneminde dil ile sembolik oyun veya dikkat, bellek gibi yürütücü işlevler arasındaki bağlantıları karşılaştırarak incelemek, benzer ölçümleme işlemlerinde ortak dil sorunlarını gözleme bakımından katkı sağlayabilir.

\section{Yazarların Katkı Düzeyi}

Yazarlar araştırmanın tüm bölümlerinde eşit düzeyde görev almışlardır. 